\title{
Current Research Trends on the Effects of Microplastics in Soil Environment Using Earthworms: Mini-Review
}

\author{
Jaeryung Hur ${ }^{1 \odot} \cdot$ Eun Hea $\mathrm{Jho}^{2,+\odot}$ \\ ${ }^{1}$ Department of Biological Sciences, Seoul National University \\ ${ }^{2}$ Department of Agricultural and Biological Chemistry, Chonnam National University
}

(Received March 4, 2021; Revised April 12, 2021; Accepted April 20, 2021)

Objectives: The increase in the amount of plastics used has brought convenience to human life, but has also caused various environmental problems such as problems related to microplastics. Microplastics are defined as small plastic particles with a size of under $5 \mathrm{~mm}$. As of now, research on microplastics has been largely focusing on the marine environment, and studies on microplastics in soil environment are on the rise in very recent years. Thus, the environmental impact of microplastics on the soil environment are insufficient than those on the marine environment, and there is a need for more studies. Therefore, this mini-review attempts to examine the studies on microplastics in soil environment focusing on the studies using earthworms as a test species.

Methods: Published studies on microplastics in soil environment were identified by searching Web of Science. The focus of this mini-review was to gather the published articles reporting the effect of microplastics on earthworms in the absence and presence of other chemical contaminants.

Results and Discussions: The number of studies evaluating the effect of microplastics in soil are significantly increasing, and earthworms are being mostly used as the test species. Experimental conditions were divided into two types: Single exposure to microplastics and combined exposure to microplastics and other chemicals. In most studies, changes in the biomarkers which are related to oxidation stress of earthworms were confirmed, and direct damage to intestinal tissues of earthworms was also observed. However, in the case of the changes of the biomarkers of earthworms, their patterns were different depending on the experimental conditions (i.e., concentrations of microplastics and chemicals, microplastics size and type, exposure period, etc.). Also, the avoidance behavior of earthworms and the internal accumulation of microplastics and co-existing chemicals were not consistent among the studies. Thus, the effects of microplastics on earthworms are not clear yet, although they seem to have some adverse effects.

Conclusions: This study showed that the interest in the impact of microplastics in the soil environment has been increased recently, and earthworms are being used mostly in the studies. Yet, there is no standardized method to study the effect of microplastics on earthworms. Studies so far confirmed that microplastics induced changes in and outside of earthworm bodies. However, due to various experimental conditions, it seemed that consistent results could not be confirmed in those researches. For that reason, this study suggests that standardized research methods for microplastics researches using earthworms as a test species need to be established and need to be applied to further studies.

Keywords : Microplastics, Soil Environment, Earthworms, Ecotoxicity 


\section{Introduction}

For reasons of convenience and economic feasibility, plastics have become an essential element in everyday life and in various industrial fields including construction, medical care, and agriculture. Plastics production has been increasing every year since 1950, when plastics production was measured. ${ }^{1)}$ Accordingly, there are increasing concerns and researches on environmental problems caused by plastic waste. In particular, one of the serious problems recognized is related to microplastics.

There are various types of plastics, on the basis of the polymer used to make the plastics, including polystyrene (PS), polyethylene (PE), polyvinyl chloride (PVC), and polyethylene terephthalate (PET). The US Environmental Protection Agency (US EPA) reported on marine microplastics under the name of plastic pellets for the first time in 1992, and classified microplastics into small plastics with a diameter of 1-5 mm in various shapes and colors. ${ }^{2)}$ Microplastics are again classified into primary microplastics and secondary microplastics. ${ }^{3)}$ Primary microplastics refer to microplastics that are manufactured for different purposes such as cosmetics and clothing and discharged directly to the environment. ${ }^{4)}$ Secondary microplastics are microplastics generated from large plastic pieces through processes such as photodegradation and weathering, and it is difficult to accurately track how much are discharged to the environment as they are formed through several processes. ${ }^{4}$

Research on microplastics has mostly focused on the distribution and effects of plastics and microplastics in the marine environment. ${ }^{5)}$ Many studies showed that microplastics can be ingested by marine organisms, thereby directly and indirectly affecting their health and inducing changes in their habitats. ${ }^{\text {) }}$ Recent studies also look at the role of microplastics as a carrier of other chemicals such as heavy metals in environment. ${ }^{7)}$ However, the studies on the effects of microplastics in soil environment are relatively limited compared to the studies on the marine environment.

Among the studies on the effects of microplastics in soil environment, several studies used earthworms to evaluate the effects of microplastics on soil environment. Earthworms play an important role in the soil ecosystem, such as maintaining soil structure and decomposing organic substances, and are used as an important biological indicator for soil pollutants. ${ }^{8)}$ The OECD provides guidelines for the assessment of acute toxic effects of test substances on earthworms ${ }^{9}$ and the

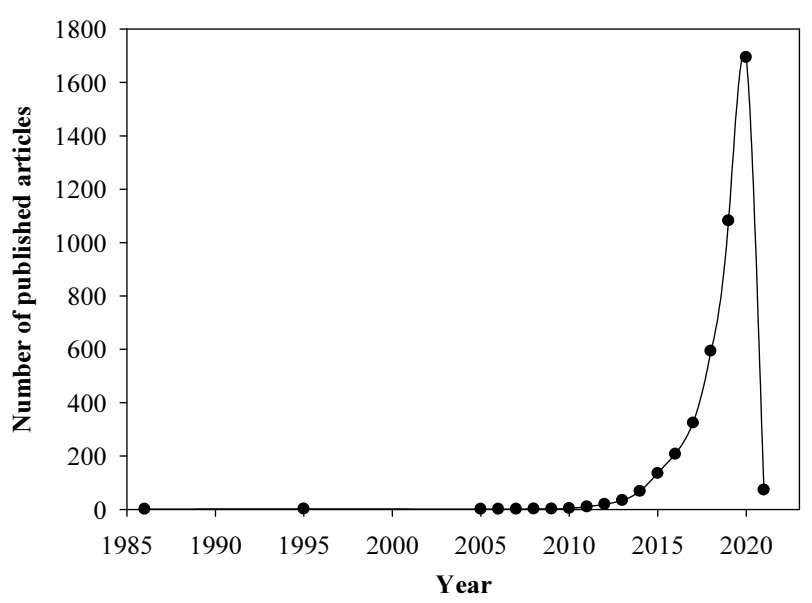

Fig. 1. Research articles on microplastics published between 1986 and 2021 (Retrieved in January 2021 from the Web of Science database by searching with keyword "microplastics". A total number of 4,253 publications were retrieved.).

assessment of the effects of test substances on earthworm reproduction ${ }^{10)}$, and many studies using earthworms follow these guidelines, but they were not prepared for testing the effects of microplastics.

Therefore, this review paper aims to summarize the recent studies on the effects of microplastics on earthworms in soil environment to help future studies on the effects of microplastics using earthworms. The Web of Science Core Collection database was used to search for the literature on how microplastics affect the environment, and there were about 4,200 journal articles published from 1986 to 2021 (i.e., search in January 2021) (Fig. 1).

\section{Research trends on microplastics}

Research on microplastics is on the rise in recent years as supported by the number of papers published shown in Fig. 1. Up to 2014 , the annual number of article published was less than 100, but it grew rapidly after that (Fig. 1). In the last few years (i.e., 2018-2020), more articles were published than the sum of all the previous years. Also, there were already near 100 articles published in January 2021, suggesting that the growing trend will continue. Therefore, this study was set to analyze the recent research trends.

The studies on the effects of microplastics can be divided based on the environmental media where microplastics can exist (i.e., marine, freshwater, and terrestrial environments). The articles collected were divided into three environmental media as shown in Fig. 2. The articles on marine microplastics 


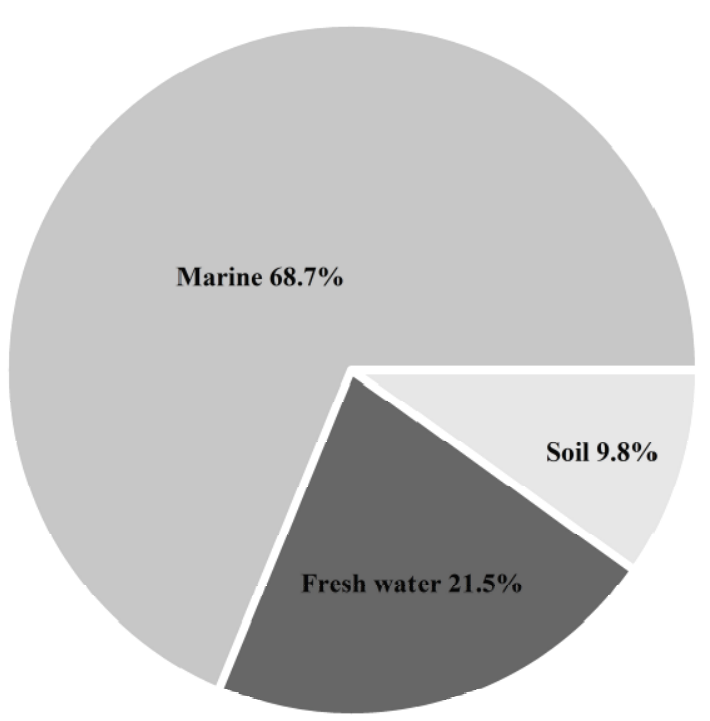

Fig. 2. Research articles on microplastics divided into three environmental media (Retrieved in January 2021 from the Web of Science database by searching with two keywords "microplastics" and "marine", "microplastics" and "fresh water (river, lake)", or "microplastics" and "soil". The number of publications in these three categories added up to 3,928 . The number of publications in "microplastics" and "marine", "microplastics" and "fresh water (river, lake)", or "microplastics" and "soil" were $2,698,845$, and 385 , respectively.).

were published from 2006 and consisted $68.7 \%$ of the articles, and this supports that the research on microplastics was mainly focused on the marine microplastics so far. The research on freshwater microplastics (21.5\%) followed that of marine microplastics, and the articles were seen from 2011 (Fig.2). Lastly, the articles on terrestrial microplastics only take $9.8 \%$ of the microplastics research, and the articles started to appear from 2016. While plastics are produced and used on the terrestrial environment and the wastes are released to the marine environment, the research on their effects is on the reverse order (i.e., from marine environment to terrestrial environment). In other words, research on terrestrial microplastics are relatively new compared to microplastics in other environmental media. However, the growth rate of the number of articles on terrestrial microplastics between 2016 and 2020 was 2.3 , on average, which is higher than the growth rates in other media (i.e., 1.6 for marine environment and 1.8 for freshwater environment). This suggests that the research on terrestrial microplastics has become more active in recent years. Thus, this review focuses on the terrestrial microplastics.

The effects of microplastics have been studied using various organisms, in particularly, aquatic organisms such as daphnids

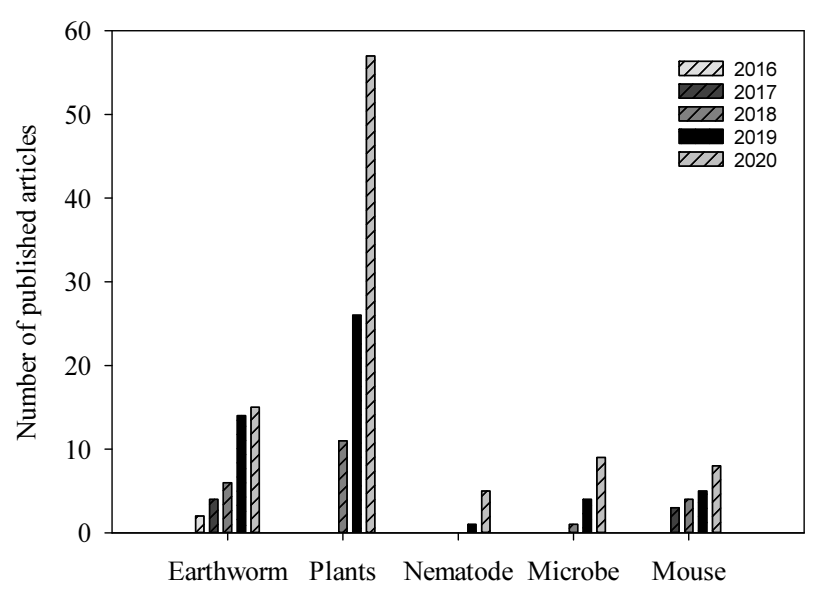

Fig. 3. Articles on the effect of microplastics using different terrestrial organisms (Retrieved in January 2021 from the Web of Science database by searching with three keywords "microplastics", "soil", and "earthworm" (43 publications), "microplastics", "soil", and "plants" (99 publications), "microplastics", "soil", and "nematode" (6 publications), "microplastics", "soil", and "microbe" (15 publications), and "microplastics", "soil", and "mouse" (21 publications)).

(e.g., Daphnia magna) $)^{11-15)}$, fish (e.g., zebrafish) ${ }^{16-19)}$, crustaceans (e.g., crab, brine shrimp) ${ }^{20-22)}$, echinoderms (e.g., sea urchin) $)^{23,24)}$, and polychaetes (e.g., Perinereis aibuhitensis). ${ }^{25)}$ With organisms residing in soil environment, the number of studies on plants increased significantly since 2018 and are the highest among other terrestrial organisms (Fig. 3). Studies using earthworms started to appear in 2016, and have been continuously increased since then (Fig. 3). Compared to the studies using aquatic organisms (i.e., both marine and freshwater organisms), only a fewer species (e.g., earthworms, rats, and nematodes) were used in the studies using terrestrial organisms. There are more publications on the studies using plants than the studies using earthworms (Fig.3), so there will be more gaps to fill in the future for the studies using earthworms. With other terrestrial organisms, there are not enough studies to review. Therefore, this review focuses on the studies using earthworms.

\section{Research trends on the effect of microplastics} on earthworms

Earthworms are widely used to investigate the soil ecotoxicity. ${ }^{26,27)}$ The studies using earthworms can be divided into two groups - single exposure of microplastics to earthworms (Table 1) and combined exposure of microplastics and other chemicals such as heavy metals, herbicides, and 
Table 1. Previous studies on the exposure of earthworms to microplastics.

\begin{tabular}{|c|c|c|c|c|c|c|}
\hline Species & $\begin{array}{l}\text { Plastic } \\
\text { type }\end{array}$ & Size / Shape & Concentration & $\begin{array}{l}\text { Exposure } \\
\text { time (d) }\end{array}$ & Biological effect & Reference \\
\hline $\begin{array}{l}\text { Lumbricus } \\
\text { terrestris }\end{array}$ & $\mathrm{PE}$ & $40.7 \mu \mathrm{m} /$ Fiber & $\begin{array}{l}0,0.1,1.0 \% \mathrm{w} / \mathrm{w} \\
\quad \text { (plastic/soil) }\end{array}$ & 35 & $\begin{array}{l}\text { - Changes in stress biomarker responses (metallothionein-2, } \\
\text { heat shock protein, superoxide dismutase (SOD)) }\end{array}$ & 28) \\
\hline Eisenia fetida & LDPE & $\begin{array}{l}250 \mu \mathrm{m} \sim 1 \mathrm{~mm} / \\
\text { Particle }\end{array}$ & $\begin{array}{l}62.5,125,250,500 \\
100 \mathrm{mg} / \mathrm{kg} \text { soil }\end{array}$ & 28 & $\begin{array}{l}\text { - Changes in antioxidant enzyme activities (glutathione } \\
\text { S-transferase (GST), catalase (CAT)) }\end{array}$ & 29) \\
\hline $\begin{array}{l}\text { Enchytraeus } \\
\text { crypticus }\end{array}$ & PS & $0.05 \sim 0.1 \mu \mathrm{m} /$ Sphere & $\begin{array}{l}0,0.025,0.5,10 \% \mathrm{w} / \mathrm{w} \\
\quad \text { (plastic/oatmeal) }\end{array}$ & 7 & $\begin{array}{l}\text { - Weight loss at the highest PS concentration } \\
\text { - Changes in the earthworm microbiome }\end{array}$ & 30) \\
\hline Eisenia fetida & LDPE & 100 200 um / Sphere & $\begin{array}{l}0.1,0.25,0.5 \\
1.0,1.5 \mathrm{~g} / \mathrm{kg} \text { soil }\end{array}$ & $7 \sim 28$ & $\begin{array}{l}\text { - Microplastic accumulation } \\
\text { - Changes in antioxidant enzyme activities (CAT, } \\
\text { malondialdehyde (MDA)) } \\
\text { - Neurotoxic response (increased acetylcholinesterase (AChE) } \\
\text { activity) }\end{array}$ & 31) \\
\hline Eisenia fetida & PS & $\begin{array}{l}100 \mathrm{~nm}, 1300 \mathrm{~nm} / \\
\text { Sphere }\end{array}$ & $\begin{array}{l}0,100,1000 \mu \mathrm{g} / \mathrm{kg} \\
\text { soil }\end{array}$ & 14 & $\begin{array}{l}\text { - Changes in antioxidant enzyme activities (SOD, glutathione } \\
(\text { GSH)) } \\
\text { - PS accumulation in intestines and tissue damage }\end{array}$ & 32) \\
\hline $\begin{array}{l}\text { Lumbricus } \\
\text { terrestris }\end{array}$ & $\begin{array}{l}\text { PS, PP, } \\
\text { PET, LDPE }\end{array}$ & $\begin{array}{l}250 \mu \mathrm{m} / \text { Irregular, } \\
\text { heterogeneous }\end{array}$ & $\begin{array}{c}2.5,5,7 \% \mathrm{w} / \mathrm{w} \\
\text { (plastic mixture/soil) }\end{array}$ & 2 & $\begin{array}{l}\text { - Neurotoxic response (changes in AChE activity) } \\
\text { - No distinction of soil with and without microplastics by } \\
\text { earthworms } \\
\text { - Presence of microplastics in the earthworm body segments }\end{array}$ & 33) \\
\hline Eisenia andrei & PE & $\begin{array}{c}\text { 180 212 } \mu \mathrm{m}, \\
250 \sim 300 \mu \mathrm{m} / \text { Sphere }\end{array}$ & $1000 \mathrm{mg} / \mathrm{kg}$ soil & 21 & $\begin{array}{l}\text { - Damage to male reproductive organs } \\
\text { - Digestion of microplastics and excretion of nanoplastics }\end{array}$ & 34) \\
\hline $\begin{array}{l}\text { Eisenia fetida, } \\
\text { Metaphire } \\
\text { guillelmi }\end{array}$ & EPS & $\begin{array}{l}830 \sim 2000 \mu \mathrm{m},<830 \mu \mathrm{m} \\
\text { / Irregular (ground with } \\
\text { a grinder) }\end{array}$ & $\begin{array}{l}0.25 \% \mathrm{w} / \mathrm{w} \\
\text { (plastic/soil) }\end{array}$ & $14 \sim 28$ & $\begin{array}{l}\text { - Hexabromocyclododecanes (HBCDDs) accumulation in } \\
\text { earthworms } \\
\text { - Smaller microplastics facilitate the bioaccumulation of } \\
\text { microplastics } \\
\text { - Bioaccumulation level differences depending on the species }\end{array}$ & 35) \\
\hline $\begin{array}{l}\text { Lumbricus } \\
\text { terrestris }\end{array}$ & LDPE & $\begin{array}{l}\text { Distribution: } 50 \% 250 \\
\mu \mathrm{m} \sim 1 \mathrm{~mm}, \\
30 \% 150 \sim 250 \mu \mathrm{m} \text { and } \\
20 \%<150 \mu \mathrm{m} / \text { Sphere }\end{array}$ & $\begin{array}{l}\text { 7\% w/w } \\
\text { (plastic/Populus nigra } \\
\text { dry litter) }\end{array}$ & 14 & $\begin{array}{l}\text { - Earthworms can act as pathways for microplastics into } \\
\text { deeper soil layers } \\
\text { - Microplastics on the soil surface could be reach to ground } \\
\text { water }\end{array}$ & 36) \\
\hline
\end{tabular}

Note: PE : Polyethylene, LDPE : Low density polyethylene, PS : Polystyrene, PP : Polypropylene, PET : Polyethylene terephthalate, EPS : Expanded polystyrene foam.

insecticides to earthworms (Table 2). The earthworm species used in the studies include Eisenia fetida (Eisenia foetida), Lumbricus terrestris, Enchytraeus crypticus, Metaphire californica. The earthworms were exposed to microplastics or to microplastics and contaminants for mostly $14 \mathrm{~d}$ or $28 \mathrm{~d}$, and some studies used exposure periods of as short as $2 \mathrm{~d}^{33)}$ and as long as $42 \mathrm{~d}^{45}$ ) For these tests, various types and sizes (from a few $\mathrm{nm}$ to a few $\mathrm{mm}$ ) of microplastics were used at different concentrations to study the effect of microplastics on earthworms. Also, when other contaminants were used in the studies, different types and concentrations of contaminants were used.

\subsection{Single exposure to microplastics}

The studies in which earthworms were exposed to only microplastics are shown in Table 1. When earthworms were exposed to microplastics, the activities of oxidative stress biomarkers tended to change. The changes in the stress biomarker activities ${ }^{28)}$ and the activities of antioxidant enzymes such as glutathione S-transferase (GST), catalase (CAT), and malondialdehyde (MDA) $)^{29,31,32)}$ were observed in several previous studies. However, one study reported that the changes in the biomarker activities at the molecular level were not significant, although the changes of the same biomarker activities were observed at the gene level. ${ }^{29)}$ In addition to the stress biomarkers, the activity of acetylcholinesterase (AChE), which is involved in the neurotransmission process, was also changed $^{33)}$ suggesting that microplastics can act as neurotoxic substances.

Apart from these in vivo changes, direct internal tissue damages of earthworms by microplastics were also observed through various histological methods. For example, larger microplastics (i.e., 1,300 nm) resulted in greater intestinal damage of earthworms than smaller microplastics (i.e., 100 $\mathrm{nm}$ ), and the accumulation of microplastics in the intestine was observed. ${ }^{32)}$ Also, microplastics were observed in different parts of earthworms suggesting that earthworms considered microplastics as food. ${ }^{33)}$ Earthworms break down the ingested microplastics and excrete them to soil. ${ }^{34)}$ In addition, microplastics had adverse effects on the sperm formation process of earthworms. ${ }^{34)}$ Overall, previous studies showed that earthworms exposed to microplastics experience changes 
Table 2. Previous studies on the combined exposure of earthworms to microplastics and contaminants.

\begin{tabular}{|c|c|c|c|c|c|c|c|}
\hline Species & $\begin{array}{l}\text { Plastic } \\
\text { type }\end{array}$ & Size / Shape & Concentration & $\begin{array}{l}\text { Co-exposure } \\
\text { contaminant }\end{array}$ & $\begin{array}{l}\text { Exposure } \\
\text { time }(d)\end{array}$ & Biological effect & Reference \\
\hline $\begin{array}{l}\text { Metaphire } \\
\text { californica }\end{array}$ & PVC & $\begin{array}{l}\text { Not indicated / } \\
\text { Not indicated }\end{array}$ & 2000 mg/kg dry soil & sodium arsenate & 28 & $\begin{array}{l}\text { - bioaccumulation of arsenic (As) in earthworm tissues } \\
\text { - Lower As accumulation in the co-exposure of PVC } \\
\text { and As }\end{array}$ & 37) \\
\hline $\begin{array}{l}\text { Eisenia } \\
\text { fetida }\end{array}$ & $P E, P S$ & $\begin{array}{l}P E<300 \mu \mathrm{m}, \\
P S<250 \mu \mathrm{m} / \\
\quad \text { Sphere }\end{array}$ & $\begin{array}{c}0,1,5,10,20 \% \mathrm{w} / \mathrm{w} \\
\text { (plastic/soil) }\end{array}$ & $\begin{array}{l}\text { hydrophobic } \\
\text { organic } \\
\text { contaminants } \\
\text { (HOCs) }\end{array}$ & 14 & $\begin{array}{l}\text { - changes in antioxidation activities (peroxidase (POD), } \\
\text { catalase (CAT)) } \\
\text { - microplastic particles in earthworm excreta }\end{array}$ & 38) \\
\hline $\begin{array}{l}\text { Eisenia } \\
\text { fetida }\end{array}$ & LDPE & $\begin{array}{l}5 \mathrm{~mm} \\
250 \text { um-1 mm } \\
\quad \text { / Particle }\end{array}$ & $\begin{array}{l}\text { - } 40 \text { each of } 5 \mathrm{~mm} \text { LDPE } \\
\text { - } 8 \text { each of } 250 \mu \mathrm{m}-1 \mathrm{~mm} \text { LDPE } \\
\text { (spread on the surface soil of } \\
1 \mathrm{~m}^{2} \text { ) }\end{array}$ & $\begin{array}{l}\text { chlorpyrifos } \\
\text { (CFP) }\end{array}$ & 14 & $\begin{array}{l}\text { - neurotoxicity response (i.e., decreased } \\
\text { acetylcholinesterase (AChE) activity) } \\
\text { - changes in antioxidation activities (thiobarbituric acid } \\
\text { reactive substances) } \\
\text { - changes in earthworm distribution in soil }\end{array}$ & 39) \\
\hline $\begin{array}{l}\text { Lumbricus } \\
\text { terrestris }\end{array}$ & LDPE & $\begin{array}{l}<150 \mu \mathrm{m} \\
\text { / Sphere }\end{array}$ & $0,1,3,7 \%$ w/w (plastic/soil) & glyphosate & 14 & $\begin{array}{l}\text { - changes in earthworm burrow, volume and weight } \\
\text { - glyphosate transportation to deeper soil layers by } \\
\text { earthworm }\end{array}$ & 40) \\
\hline $\begin{array}{l}\text { Lumbricus } \\
\text { terrestris }\end{array}$ & HDPE & $\begin{array}{l}0.9 \pm 1.1 \mathrm{~mm}^{2} / \\
\text { Irregular } \\
\text { (manually cut) }\end{array}$ & $143 \pm 4.37$ mg/kg soil & Zinc (Zn) & 28 & $\begin{array}{l}\text { - increase in Zn bioavailability } \\
\text { - no significant changes in earthworm weight } \\
\text { - no preferential behaviors of HDPE ingestion or } \\
\text { avoidance }\end{array}$ & 41) \\
\hline $\begin{array}{l}\text { Eisenia } \\
\text { fetida }\end{array}$ & $\begin{array}{l}\text { HDPE, } \\
\text { LDPE, } \\
\text { PS, } \\
\text { PVC, } \\
\text { PP }\end{array}$ & $\begin{array}{l}\text { 250 300 } \mu \mathrm{m} \\
\text { / Sphere }\end{array}$ & $\begin{array}{c}0.1,1 \% \mathrm{w} / \mathrm{w} \\
\text { (plastic/HOC-spiked soil) }\end{array}$ & $\mathrm{HOCS}$ & 28 & $\begin{array}{l}\text { - increased HOCs accumulation in earthworm } \\
\text { - greater accumulation of HDPE, LDPE than other } \\
\text { types of plastics } \\
\text { - higher HOCs absorption at high microplastic } \\
\text { concentrations }\end{array}$ & 42) \\
\hline $\begin{array}{l}\text { Eisenia } \\
\text { fetida }\end{array}$ & $\mathrm{PE}$ & $\begin{array}{l}<300 \text { um } \\
\text { / Sphere }\end{array}$ & $\begin{array}{l}0,7,15,20,30 \% \mathrm{w} / \mathrm{w} \\
\text { (plastic/Cd-spiked soil) }\end{array}$ & Cadmium (Cd) & 28 & $\begin{array}{l}\text { - increase in Cd bioavailability } \\
\text { - increased earthworm avoidance behavior and body } \\
\text { weight loss at the highest PE concentration } \\
\text { - changes in antioxidation activities (superoxide } \\
\text { dismutase (SOD), POD, glutathione (GSH), } \\
\text { malondialdehyde (MDA)) } \\
\text { - intestinal tissue damage } \\
\text { - DNA damage }\end{array}$ & 43) \\
\hline $\begin{array}{l}\text { Eisenia } \\
\text { fetida }\end{array}$ & LDPE & $\begin{array}{l}550 \sim 1000 \mu \mathrm{m} / \\
\quad \text { Irregular }\end{array}$ & $\begin{array}{c}0.25 \% \mathrm{w} / \mathrm{w} \\
\text { (plastic/ATZ-spiked soil) }\end{array}$ & atrazine (ATZ) & 28 & $\begin{array}{l}\text { - changes in antioxidation activities (SOD, CAT, MDA, } \\
\text { 8-hydroxy } 2 \text { deoxyguanosine (8-OHdG), reactive } \\
\text { oxygen species (ROS)) } \\
\text { - changes in gene expression level (calreticulin (CRT), } \\
\text { translationally controlled tumor protein (TCTP), } \\
\text { annetocin (ANN)) } \\
\text { - higher integrated biomarker response (IBR) value in } \\
\text { the co-exposure condition at the biochemical levels }\end{array}$ & 44) \\
\hline $\begin{array}{l}\text { Eisenia } \\
\text { foetida }\end{array}$ & PP & $\begin{array}{l}<150 \mu \mathrm{m} / \\
\text { Ground particle }\end{array}$ & $\begin{array}{c}300,3000,6000,9000 \\
\mathrm{mg} / \mathrm{kg} \text { soil }\end{array}$ & $\mathrm{Cd}$ & $14 \sim 42$ & $\begin{array}{l}\text { - changes in earthworm growth rate } \\
\text { - the highest mortality after long-term exposure ( } 42 \mathrm{~d} \text { ) } \\
\text { at the highest PP concentration } \\
\text { - changes in antioxidation activities (lipid peroxides } \\
\text { (LPO), GSH) } \\
\text { - increased direct ingestion of PP with increasing } \\
\text { exposure period } \\
\text { - reduced Cd content in the earthworm body when } \\
\text { co-exposed to PP and Cd }\end{array}$ & 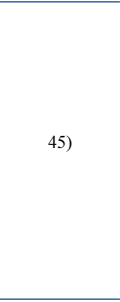 \\
\hline $\begin{array}{l}\text { Eisenia } \\
\text { foetida }\end{array}$ & PS & $\begin{array}{l}100 \mathrm{~nm} \\
1,10,100 \mu \mathrm{m} \\
\text { / Sphere }\end{array}$ & 10 mg/kg soil & $\begin{array}{l}\text { phenanthrene } \\
\text { (Phe) }\end{array}$ & $3 \sim 21$ & $\begin{array}{l}\text { - changes in earthworm growth rate } \\
\text { - increased Phe and PS contents in earthworm and } \\
\text { DNA damage under co-exposure condition } \\
\text { - changes in antioxidation activities (CAT, MDA, SOD, } \\
\text { POD) } \\
\text { - changes in gene expression level (heat shock protein } \\
\text { (Hsp70), TCTP, SOD, metallothionein (MT), CAT, } \\
\text { GST) } \\
\text { - changes in microbial community of soil and } \\
\text { earthworm }\end{array}$ & 46) \\
\hline $\begin{array}{l}\text { Eisenia } \\
\text { fetida }\end{array}$ & $\mathrm{PE}$ & $\begin{array}{l}\text { 30, } 100 \mu \mathrm{m} / \\
\text { Sphere }\end{array}$ & $\begin{array}{l}0.01,0.05,0.1 \% \mathrm{w} / \mathrm{w} \\
\text { (plastic/ } \mathrm{Ni}^{2+} \text { or } \mathrm{Cu}^{2+} \\
\text { spiked soil) }\end{array}$ & $\begin{array}{l}\text { Nickel }(\mathrm{Ni}) \\
\text { Copper }(\mathrm{Cu})\end{array}$ & $7 \sim 21$ & $\begin{array}{l}\text { - increased metal absorption of earthworms } \\
\text { - changes in antioxidant activities (MDA, SOD, CAT, } \\
\text { POD) } \\
\text { - changes in gene expression level (Hsp70, TCTP) }\end{array}$ & 47) \\
\hline
\end{tabular}

Note: PVC : Polyvinyl chloride, PE : Polyethylene, PS : Polystyrene, LDPE : Low density polyethylene, HDPE : High density polyethylene, PP : Polypropylene. 
in stress responses, direct organ damages, and neurotoxicity.

\subsection{Combined exposure to microplastics and chemicals}

The studies in which the interaction between microplastics and other chemicals and their effects on earthworms were studied are shown in Table 2. With regard to the chemical accumulation, different results have been observed by different researchers. For example, some studies showed increased microplastic accumulation by earthworms when they were exposed to microplastics in the presence of other chemicals such as heavy metals and organic compounds ${ }^{38,41-43,46)}$, and some studies reported decreased microplastic accumulation by earthworms. ${ }^{37,45)}$ The differences in the microplastic accumulation can be explained by different factors including types and concentrations of contaminants that coexist with microplastics, characteristics of microplastics (i.e., types, sizes, shapes), and exposure periods.

Similar to the studies on single exposure to microplastics, combined exposures of earthworms to microplastics and chemicals caused changes in the biomarkers related to stress. $^{38,39,43-46)}$ Combined exposure to chemicals and microplastics could also damage the nerve transmission process of earthworms ${ }^{39)}$, as observed with the earthworms exposed to only microplastics. ${ }^{33)}$ Most studies did not report direct relationship between exposure to microplastics and death of earthworms, but some reported reducted weight and growth of earthworms ${ }^{40,43,45)}$ and increased mortality. ${ }^{45)}$ The negative effects were greater when earthworms were exposed to microplastics and chemicals simultaneously. ${ }^{45)}$ The ingestion and accumulation of microplastics increased with increasing exposure period and microplastic concentrations. ${ }^{45)}$ In addition to the effects on growth and mortality, the studies on the earthworm behavior towards the microplastics contaminated with chemicals showed that earthworms tend to avoid microplastics contaminated with chemicals. ${ }^{39,40)}$ Earthworms might avoid soils contaminated with high concentrations of microplastics ${ }^{43)}$; however, they might not show such avoidance behavior. $^{41)}$ The ingestion of microplastics caused damages to internal organs and sperm DNA of earthworms. ${ }^{43)}$ Also, the absorption of microplastics by earthworms could change the bacterial activities in earthworms resulting in greater accumulation of chemicals. ${ }^{46}$

In the co-presence of chemicals such as heavy metals and microplastics, the availability of chemicals to earthworms can be affected, which, in turn, influence the amount of microplastics and chemicals accumulated in earthworms. ${ }^{45,46)}$
The co-presence of microplastics may promote the absorption of chemicals such as polycyclic aromatic hydrocarbons (PAHs) and cadmium $(\mathrm{Cd})$ by earthworms. ${ }^{45,46)}$

Overall, the exposure of earthworms to only microplastics or both microplastics and chemicals could result in changes in internal stress-related factors of earthworms; however, the types (i.e., positive or negative) and extent of changes reported so far in previous studies were not consistent. This could be attributed to the differences in the types, sizes, and concentrations of microplastics, the types and concentrations of co-existing chemicals, soil characteristics, and exposure period. Also, there is a lack of studies on the interaction between microplastics and co-existing chemicals and the effect of co-existing microplastics and chemicals on earthworms. Based on the previous studies on the effect of microplastics on earthworms, the changes in the behavior and health status of earthworms and the interactions between microplastics and chemicals could eventually lead to changes in the soil environment and soil health. Therefore, more studies on the effects of microplastics and co-existing chemicals in the soil environment need to be carried out in order to maintain the soil environment healthy.

\section{Conclusions}

The effects of microplastics and co-existing chemicals in environmental media have been receiving increasing attention, yet the studies on the soil environment are relatively limited compared to other environmental media. Earthworms are one of the most studied terrestrial species to understand the effect of microplastics. In particular, the research efforts on the effect of microplastics on earthworms have recently been increasing suggesting there is much to explore. Earthworms exposed to microplastics can ingest microplastics and these can lead to changes in the biomarkers related to oxidative stress and direct internal organ damages. However, the results are not yet consistent, probably due to the varieties in microplastics and chemicals that can be studied. Also, there is no standardized method to use when studying the effect of microplastics and co-existing chemicals in the soil environment. Therefore, more research on the effects of different microplastics (i.e., types, size, shape, etc.) on earthworms is needed in future. In addition, the standardized methods for assessing the effect of microplastics in the terrestrial environment need to be prepared to properly assess and understand the effect of microplastics on the terrestrial environment. 


\section{Acknowledgement}

This study was funded by the National Research Foundation of Korea (NRF-2018R1C1B6002702; NRF-2021R1A2C4001 746).

\section{References}

1. R. Geyer, J. R. Jambeck, K. L. Law, Production, use, and fate of all plastics ever made, Sci. Adv., 3(7), e1700782 (2017).

2. US EPA, Plastic pellets in the aquatic environment: sources and recommendations, US EPA, Duxbury, USA, pp. 1-108 (1992).

3. M. Cole, P. Lindeque, C. Halsband, T. S. Galloway, Microplastics as contaminants in the marine environment: a review, Mar. Pollut. Bull., 62(12), 2588-2597(2011).

4. J. Boucher, D. Friot, Primary microplastics in the oceans: a global evaluation of sources, Iucn Gland, Switzerland, pp. 1-44(2017).

5. J.-J. Ko, Y.-T. Jo, J.-H. Park, K.-R. Moon, B.-G. Kwon, Study on the quantitative analysis of styrene oligomers originated from styrene-based pasltic polymer materials, J. Korean Soc. Environ. Eng., 41(5), 278-285(2019).

6. S. L. Wright, R. C. Thompson, T. S. Galloway, The physical impacts of microplastics on marine organisms: a review, Environ. Pollut., 178, 483-492(2013).

7. W. J. Ju, J. An, E. H. Jho, Adsorption characteristics of Cd and $\mathrm{Pb}$ on microplastic films generated in agricultural environment, J. Korean Soc. Environ. Eng., 43(1), 32-42 (2021).

8. C. A. Edwards, Report of the second stage in development of a standardized laboratory method for assessing the toxicity of chemical substances to earthworms, Commission of the European Communities, Luxembourg, pp. 1-99(1984).

9. OECD, Test no. 207: Earthworm, acute toxicity tests, oecd guidelines for the testing of chemicals, section 2, OECD Publishing, Paris, pp. 1-7(1984).

10. OECD, Test no. 222: Earthworm reproduction test (eisenia fetida/eisenia andrei), oecd guidelines for the testing of chemicals, section 2, OECD Publishing, Paris, pp. 1-21(2016).

11. O. O. Fadare, B. Wan, L.-H. Guo, Y. Xin, W. Qin, Y. Yang, Humic acid alleviates the toxicity of polystyrene nanoplastic particles to Daphnia magna, Environ. Sci. Nano, 6(5), 1466-1477(2019).

12. Z. Gerdes, M. Ogonowski, I. Nybom, C. Ek, M. Adolfsson-Erici, A. Barth, E. Gorokhova, Microplasticmediated transport of PCBs? a depuration study with Daphnia magna, PLoS One, 14, e0205378(2019).

13. A. A. Horton, M. G. Vijver, E. Lahive, D. J. Spurgeon, C. Svendsen, R. Heutink, P. M. van Bodegom, J. Baas, Acute toxicity of organic pesticides to Daphnia magna is unchanged by co-exposure to polystyrene microplastics, Ecotoxicol. Environ. Saf., 166, 26-34(2018).
14. A. J. Kokalj, U. Kunej, T. Skalar, Screening study of four environmentally relevant microplastic pollutants: uptake and effects on Daphnia magna and Artemia franciscana, Chemosphere, 208, 522-529(2018).

15. R. Jiang, W. Lin, J. Wu, Y. Xiong, F. Zhu, L.-J. Bao, J. You, G. Ouyang, E. Y. Zeng, Quantifying nanoplastic-bound chemicals accumulated in Daphnia magna with a passive dosing method, Environ. Sci. Nano, 5(3), 776-781(2018).

16. C. W. Mak, K. Ching-Fong Yeung, K. M. Chan, Acute toxic effects of polyethylene microplastic on adult zebrafish, Ecotoxicol. Environ. Saf., 182, 109442(2019).

17. R. Qiao, K. Lu, Y. Deng, H. Ren, Y. Zhang, Combined effects of polystyrene microplastics and natural organic matter on the accumulation and toxicity of copper in zebrafish, Sci. Total Environ., 682, 128-137(2019).

18. Z. Wan, C. Wang, J. Zhou, M. Shen, X. Wang, Z. Fu, Y. Jin, Effects of polystyrene microplastics on the composition of the microbiome and metabolism in larval zebrafish, Chemosphere, 217, 646-658(2019).

19. W. J. Veneman, H. P. Spaink, N. R. Brun, T. Bosker, M. G. Vijver, Pathway analysis of systemic transcriptome responses to injected polystyrene particles in zebrafish larvae, Aquat. Toxicol., 190, 112-120(2017).

20. S. Piarulli, S. Scapinello, P. Comandini, K. Magnusson, M. Granberg, J. X. W. Wong, G. Sciutto, S. Prati, R. Mazzeo, A. M. Booth, L. Airoldi, Microplastic in wild populations of the omnivorous crab Carcinus aestuarii: a review and a regional-scale test of extraction methods, including microfibres, Environ. Pollut., 251, 117-127(2019).

21. D. Peixoto, J. Amorim, C. Pinheiro, L. Oliva-Teles, I. Varóó, R. de Medeiros Rocha, M. N. Vieira, Uptake and effects of different concentrations of spherical polymer microparticles on Artemia franciscana, Ecotoxicol. Environ. Saf., 176, 211-218(2019).

22. C. Zhang, C.-B. Jeong, J.-S. Lee, D. Wang, M. Wang, Transgenerational proteome plasticity in resilience of a marine copepod in response to environmentally relevant concentrations of microplastics, Environ. Sci. Technol., 53(14), 8426-8436(2019).

23. M. Oliviero, T. Tato, S. Schiavo, V. Fernáández, S. Manzo, R. Beiras, Leachates of micronized plastic toys provoke embryotoxic effects upon sea urchin Paracentrotus lividus, Environ. Pollut., 247, 706-715(2019).

24. S. Messinetti, S. Mercurio, M. Parolini, M. Sugni, R. Pennati, Effects of polystyrene microplastics on early stages of two marine invertebrates with different feeding strategies, Environ. Pollut., 237, 1080-1087(2018).

25. J. Leung, K. Y. K. Chan, Microplastics reduced posterior segment regeneration rate of the polychaete Perinereis aibuhitensis, Mar. Pollut. Bull., 129, 782-786(2018).

26. D. Kim, S. W. Kim, Y.-J. An, Research trend for on-site soil ecotoxicity evaluation methods for field soil, J. Korean Soc. Environ. Eng., 41(3), 125-131(2019).

27. S.-H. Nam, Y.-J. An, Investigation of Korean native organisms for development of ecotoxicity test: (2) soil test 
species, J. Korean Soc. Environ. Eng., 40(1), 48-57(2018).

28. M. T. Prendergast-Miller, A. Katsiamides, M. Abbass, S. R. Sturzenbaum, K. L. Thorpe, M. E. Hodson, Polyester-derived microfibre impacts on the soil-dwelling earthworm Lumbricus terrestris, Environ. Pollut., 251, 453-459(2019).

29. A. Rodríuez-Seijo, J. P. da Costa, T. Rocha-Santos, A. C. Duarte, R. Pereira, Oxidative stress, energy metabolism and molecular responses of earthworms (Eisenia fetida) exposed to low-density polyethylene microplastics, Environ. Sci. Pollut. Res. Int., 25(33), 33599-33610(2018).

30. B.-K. Zhu, Y.-M. Fang, D. Zhu, P. Christie, X. Ke, Y.-G. Zhu, Exposure to nanoplastics disturbs the gut microbiome in the soil oligochaete Enchytraeus crypticus, Environ. Pollut., 239, 408-415(2018).

31. Y. Chen, X. Liu, Y. Leng, J. Wang, Defense responses in earthworms (Eisenia fetida) exposed to low-density polyethylene microplastics in soils, Ecotoxicol. Environ. Saf., 187, 109788(2020)

32. X. Jiang, Y. Chang, T. Zhang, Y. Qiao, G. Klobučr, M. Li, Toxicological effects of polystyrene microplastics on earthworm (Eisenia fetida), Environ. Pollut., 259, 113896 (2020).

33. C. Baeza, C. Cifuentes, P. Gonzáez, A. Araneda, R. Barra, Experimental exposure of Lumbricus terrestris to microplastics, Water Air Soil Pollut., 231, 308(2020).

34. J. I. Kwak, Y.-J. An, Microplastic digestion generates fragmented nanoplastics in soils and damages earthworm spermatogenesis and coelomocyte viability, J. Hazard. Mater., 402, 124034(2021).

35. B. Li, Z. Lan, L. Wang, H. Sun, Y. Yao, K. Zhang, L. Zhu, The release and earthworm bioaccumulation of endogenous hexabromocyclododecanes (HBCDDs) from expanded polystyrene foam microparticles, Environ Pollut., 255, 113163(2019).

36. M. Yu, M. Van Der Ploeg, E. H. Lwanga, X. Yang, S. Zhang, X. Ma, C. J. Ritsema, V. Geissen, Leaching of microplastics by preferential flow in earthworm (Lumbricus terrestris) burrows, Environ. Chem., 16(1), 31-40(2019).

37. H.-T. Wang, J. Ding, C. Xiong, D. Zhu, G. Li, X.-Y. Jia, Y.-G. Zhu, X.-M. Xue, Exposure to microplastics lowers arsenic accumulation and alters gut bacterial communities of earthworm Metaphire californica, Environ. Pollut., 251, 110-116(2019).

38. J. Wang, S. Coffin, C. Sun, D. Schlenk, J. Gan, Negligible effects of microplastics on animal fitness and hoc bioaccumulation in earthworm Eisenia fetida in soil, Environ. Pollut., 249, 776-784(2019).

39. A. Rodríuez-Seijo, B. Santos, E. Ferreira da Silva, A. Cachada, R. Pereira, Low-density polyethylene microplastics as a source and carriers of agrochemicals to soil and earthworms, Environ. Chem., 16(1), 8-17(2019).

40. X. Yang, E. H. Lwanga, A. Bemani, H. Gertsen, T. Salanki, X. Guo, H. Fu, S. Xue, C. Ritsema, V. Geissen, Biogenic transport of glyphosate in the presence of LDPE microplastics: a mesocosm experiment, Environ. Pollut., 245, 829-835
(2019).

41. M. E. Hodson, C. A. Duffus-Hodson, A. Clark, M. T. Prendergast-Miller, K. L. Thorpe, Plastic bag derived microplastics as a vector for metal exposure in terrestrial invertebrates, Environ. Sci. Technol., 51(8), 4714-4721(2017).

42. J. Wang, S. Coffin, D. Schlenk, J. Gan, Accumulation of HOCs via precontaminated microplastics by earthworm Eisenia fetida in soil, Environ. Sci. Technol., 54(18), 11220-11229(2020).

43. C. Huang, Y. Ge, S. Yue, L. Zhao, Y. Qiao, Microplastics aggravate the joint toxicity to earthworm Eisenia fetida with cadmium by altering its availability, Sci. Total Environ., 753, 142042(2021).

44. Y. Cheng, L. Zhu, W. Song, C. Jiang, B. Li, Z. Du, J. Wang, J. Wang, D. Li, K. Zhang, Combined effects of mulch film-derived microplastics and atrazine on oxidative stress and gene expression in earthworm (Eisenia fetida), Sci. Total Environ., 746, 141280(2020).

45. Y. Zhou, X. Liu, J. Wang, Ecotoxicological effects of microplastics and cadmium on the earthworm Eisenia foetida, J. Hazard. Mater., 392, 122273(2020).

46. G. Xu, Y. Liu, X. Song, M. Li, Y. Yu, Size effects of microplastics on accumulation and elimination of phenanthrene in earthworms, J. Hazard. Mater., 403, 123966 (2021).

47. M. Li, Y. Liu, G. Xu, Y. Wang, Y. Yu, Impacts of polyethylene microplastics on bioavailability and toxicity of metals in soil, Sci. Total Environ., 760, 144037(2021).

\section{Declaration of Competing Interest}

The authors declare that they have no known competing financial interests or personal relationships that could have appeared to influence the work reported in this paper.

\section{Authors and Contribution Statement}

\section{Jaeryung Hur}

Department of Biological Sciences, Seoul National University, MSc, ORCID (1) 0000-0003-3738-2607: Conceptualization, Data analysis, Methodology, Visualization, Writing - original draft, Writing review and editing.

\section{Eun Hea Jho}

Department of Agricultural and Biological Chemistry, Chonnam National University, Associate Professor, ORCID (1) 0000-0003-0098 -7338: Conceptualization, Data analysis, Funding acquisition, Methodology, Project administration, Resources, Supervision, Validation, Writing - original draft, Writing - review and editing. 